\title{
QUESTIONNAIRE FOR READERS
}

Insofar as possible the Editors will select reviewers from among the readers of the JOURNAL. They therefore request all readers to fill out and return this form to The Editors, JOURNAL OF ECONOMIC HISTORY, 'BOx 4l, Administration Building, Emory University, Atlanta, Georgia 30322.

Nasue (last name first):

Address :

Institutional affiliation (if not in address) and academic status :

Areas of scholarly competence:

Languages (other than English) in which you have a reading proficiency:

Representative recent publications (maximum of five): 


\title{
THE
}

\section{ECONOMIC HISTORY}

\author{
ASSOCIATION
}

\section{7}

\section{DIRECTORY OF MEMBERS}

Price: $\$ 2.50$ to Members; $\$ 5.00$ for Others.

Enclose payment with order and send to:

R. D. Williams, Treas., Box 3630

Wilmington, Del. 19807

\section{Electricity before Nationalisation}

A Study of the Development of the Electricity Supply

Industry in Britain to 1948

\section{Leslie Hannah}

Britain's electricity supply industry exemplifies, demonstrably more than any other, the modern interaction of technical change, mass production, and rising living standards. This account of a major British industry examines how government ownership of the nation's private and municipal electrical companies came to be the only workable solution to the problem of meeting the nation's needs.

$\$ 28.50$

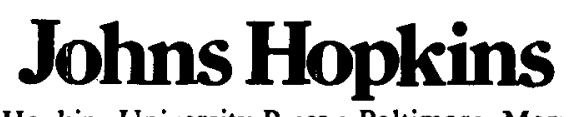

The Johns Hopkins University Press - Baltimore, Maryland 21218 


\section{New Books in the Social Sciences from Cambridge University Press/ Editions de la Maison des Sciences de l'Homme, Paris}

A joint publishing arrangement has been established between Cambridge University Press and the Maison des Sciences de l'Homme, Paris.

The Maison, which is dedicated to the promotion of the social and human sciences, encourages, organizes, and sponsors discussion and collaboration among researchers from throughout the international community. Works published under this joint imprint will reflect the varied interests of the Maison and the institutions associated with it, as well as those of the many contacts the Maison maintains with scholars from continental Europe and the Englishspeaking world. There will be works in English, French, Italian, and probably German, and some of the collaborative volumes will be multi-lingual. Most of the books will fall into one of the following series:

\section{Atelier d'Anthropologie Sociale \\ Louis Dumont, Editor}

Books in this series will be primarily written by scholars associated with the 'Co-operative Research Programme No. 436' of the Center National de la Recherche Scientifique, Paris, but will be open to contributions from authors with a similar perspective. Works will combine the development of theory with ethnographic precision and will not be limited either geographically or thematically.

\section{Studies in Modern Capitalism/Études sur le Capitalisme Moderne}

Editorial Board: Maurice Aymard, Jacques Revel, Immanuel Wallerstein

A joint enterprise of the Maison and the Fernand Braudel Center for the Study of Economies, Historical Systems, and Civilizations at the State University of New York, Binghamton, this series is an attempt to comprehend capitalism as a world-system. It will include monographs-written in English or Frenchcollections of essays, and colloquia-mainly multi-lingual-written by historians and social scientists united by a common concern for the study of large-scale, long-term social structure and social change.

\section{A Series of Volumes based on Colloquia organized in the context of the Maison des Sciences de I'Homme/Une collection d'ouvrages composés à partir de colloques organises dans le cadre de la Maison des sciences de l'homme.}

\footnotetext{
The sponsoring and organization of international conferences on a wide range of topics in the human and social sciences forms a large part of the Maison's activities. Volumes in this series will be based on these colloquia and will be multi-lingual.
} 


\section{Studies in Modern Capitalism/ Etudes sur le Capitalisme Moderne}

\section{THE CAPITALIST WORLD-ECONOMY IMMANUEL WALLERSTEIN}

In this collection of his essays, Wallerstein focuses on the central conflicts of capitalism-bourgeois vs. proletarian and core vs. periphery -in an attempt to describe both the cyclical rhythms and the secular transformations of capitalism, conceived as a singular world-system. His writings are informed by a strong commitment to the unidisciplinarity of the historical social sciences, to a dialectical methodology, and to a belief that social analysis is never value-free.

Hardcover $\$ 36.00$ Paper $\$ 9.95$

\section{ALGERIA 1960 \\ PIERRE BOURDIEU}

This book centers on Bourdieu's classic essay, The Disenchantment of the World, which analyzes the relationship between economic structures and the structures of the experience of time, e.g. saving or hoarding. The second part of the book contains two studies in Kabyle ethnography.

$\$ 19.95$

\section{MEXICAN AGRICULTURE 1521-1630}

Transformation of the Mode of Production

ANDRE GUNDER FRANK

Analyzes the transformation of Mexican agriculture and society after the Spanish conquest in terms of the development of the world capitalist system. Frank discusses the continual transformation of economic, social and political institutions, and shows how the local economic, social and political process is determined by a combination of local conditions and the imperatives of world-capitalist development.

$\$ 13.95$

\section{Cambridge University Press}

32 East 57th Street, New York, N.Y. 10022 


\title{
THE ECONOMIC RISE OF EARLY AMERICA
}

\author{
GARY M. WALTON and JAMES F. SHEPHERD
}

Surveys the major developments in the colonial economy from the days of early settlement through the Revolutionary War. Walton and Shepherd examine regional economic differences, trends in colonial output, rates of growth, and important demographic changes, and pay considerable attention to the role of mercantilist forces, the expansion of shipping and trade, and the special significance of overseas markets. Emphasizing the role of British capital in colonial development, the authors conclude with an assessment of the effects of the Revolution and independence on shipping activity and trade.

Hardcover $\$ 19.95$ Paper $\$ 4.95$

\section{SHIPPING, MARITIME TRADE AND THE ECONOMIC DEVELOPMENT OF COLONIAL NORTH AMERICA}

\section{JAMES F. SHEPHERD and GARY M. WALTON}

Using quantitative analysis, the authors offer a close examination of the North American colonial economy from the mid-17th century to the Revolution, placing in perspective the importance of increasing market trade and regional specialization, and the pace and pattern of the economic development in general. Shipping and overseas trade are discussed in detail.

$\$ 19.95$

\section{Cambridge University Press}

32 East 57th Street, New York, N.Y. 10022 